\section{Mathematical modelling of transport phenomena in concrete porous media}

\begin{abstract}
ILIJA PLEĆAŠ = Institute of Nuclear Sciences “Vinča” - iplecac@vin.bg.ac.yu
Szállítási jelenségek matematikai modellezése porózus beton közegben

Amikor egy felszíni hulladéklerakóban elhelyezett alacsony szintú nukleáris hulladék anyagok elszigetelését kívánjuk megoldani, két alapvetô problémával találkozunk. Az elsố a hulladék anyagok elszigetelése a víztôl, azaz a hidrológiai elkülönítés. A másik a radionukleidek a hulladéklerakóból való kijutásának, azaz a radionukleidek elvándorlásának a megakadályozása. E munkában különösen az utóbbi, módosított eshetôségeket vizsgáltuk. A radioaktív hulladékból és betonból készített keverékek ártalmatlanítása biztonságának felmérése érdekében azt tanulmányoztuk, hogyan szivárog ki az ilyen kompozit hulladék anyagból a 60-as rendszámú kobalt $\left({ }^{60} \mathrm{Co}\right)$ a környezô talajvízbe. A szivárgási vizsgálatot a Vinca Intézet által kifejlesztett eredeti módszerrel [1, 2, 3, 4, 5] végeztük. A radioaktív anyag egy cementes kompozit mátrixból való kiszivárgásának szállítási jelenségeit az elméleti egyenleteken [6, 10] alapuló három módszer alkalmazásával vizsgáltuk. Ezek a következők voltak: egy sima forrásra vonatkozó diffúziós egyenlet, egy elsô fokú egyenlettel párosított diffúziós egyenlet, és egy polinom egyenletet használó empirikus módszer. Az e cikkben ismertetett eredmények egy 25 évre tervezett habarcs- és betonvizsgálati projektből származnak, amely kihat majd egyjövôbeli, szerbiai radioaktív hulladékot tároló központnál a radioaktív hulladékok “becsomagolására” alkalmazandó tervezési megoldásokra.

Kulcsszavak: radioaktív hulladék, cement, beton, szállítási jelenségek, szivárgási sebesség

Keywords: radioactive waste, cement, concrete, transport phenomena, leakage rate
\end{abstract}

Dr. Ilija B. Plećaš received the degree of B.Sc. Chem.Eng, Mr Sci and Ph.D. at the Faculty of Technology at the Belgrade University. He has been employed in the Radiation and Environmental Protection Laboratory in the "VINČA" Institute of Nuclear Sciences" since 1973 and constantly engaged in research and design in the field of radioactive waste treatment, storing and disposal, specially

in the field of immobilization of radioactive waste by cement. He published more than 40 papers in International Journals and more than 80 papers on International Conferences and Symposia. In the period 1992-1999, he has been Head of the Radiation and Environmenta Protection Department in the "Vinča" Institute of Nuclear Sciences. In the period 1999-2001, he has been Acting director of "VINČA" Institute of Nuclear Science Belgrade, Serbia. Member of the Scientific Society of Serbia.

\section{Introduction}

Cement and concrete are widely used in low-level waste management both as a means of solidifying waste and for containment of dry or liquid wastes. At present there is also widespread interest in the use of near-surface concrete trench system for the disposal of radwaste materials. Typical concrete is a mixture of cement, sand, stone aggregate and water in various proportions that together determine the structural properties and tightness of the poured material. Water content is one of the critical parameters and must be carefully controlled during purring and setting; to a large extent it will determine the porosity of the resulting material.

Engineered barriers are features of the disposal system made or altered by humans during the construction, operation and closure of a repository. Engineered barriers are intended to contribute to the overall performance of the disposal system by providing the level of containment required while the waste remains hazardous. In cases where the selected site or geological environment is not ideally suited for disposal, the repository can be heavily engineered so that, for meeting safety targets, reliance is placed primarily on the engineered barriers.

Engineering trenches system provides three biological protection barriers:

1. Mortar for immobilizing the waste and filling the concrete containers. (enable its penetration into all cavities of solid radioactive waste and thus fix it permanently; permit no leakage of radionuclides- use of special cement or adsorbers and provide primary biological protection)

2. Concrete container (store and enable transport of low and intermediate level radioactive waste; provide secondary biological protection; provide safe keeping of radioactive waste for $300-500$ years)
3. Concrete for filling trenches (provide tertiary biological protection and prevent leakage of radionuclides which have penetrated the second barrier)

At the "Vinca" Institute of Nuclear Sciences, a promising composite for engineer trenches system, especially for concrete for filling trenches has been developed. Leakage test for leakage measurements of radionuclides from concrete was studied using the above method $[1,3,7,8,9,11]$.

\section{Theoretical methods}

Three methods are compared with respect to their applicability to experimental leaching data $[6,10,13,14]$.

Method I: Diffusion equation based on a plane source model

In this model the fraction $\mathrm{f}$ leached at time $\mathrm{t}(\mathrm{d})$ :

$$
f=\frac{\sum a_{n}}{A_{o}}=\frac{2 S \sqrt{D_{e} t_{n}}}{V \sqrt{\pi}}
$$

where $\Sigma a_{n}$ is the cumulative fraction leached of contaminant for each leaching period, $\mathrm{A}_{\mathrm{o}}$ is the initial amount of contaminant in the sample, $\mathrm{V}$ is the volume of sample $\left(\mathrm{cm}^{3}\right), \mathrm{S}$ is the exposed surface area of the sample $\left(\mathrm{cm}^{2}\right), \mathrm{t}_{\mathrm{n}}$ the duration of leachant renewal period (d) and $D_{e}$ is the diffusion coefficient $\left(\mathrm{cm}^{2} \mathrm{~d}^{-1}\right)$

The results may also be expressed by the cumulative fraction of the contaminant. Leach test results are plotted as the cumulative fraction of contaminant leached from the samples as a function of the square root of total leaching time:

$$
\frac{\sum a_{n}}{A_{o}} \text { versus } \sqrt{\sum_{t_{n}}}
$$


If the model is applicable a plot of $\Sigma \mathrm{a}_{\mathrm{n}} / \mathrm{A}_{\mathrm{o}}$ versus $\sqrt{ } \Sigma \mathrm{t}_{\mathrm{n}}$ is a straight line and the diffusion coefficient $\mathrm{D}_{\mathrm{e}}$ is given by:

$$
D_{e}=\frac{\pi}{4} m^{2} \frac{V^{2}}{S^{2}}
$$

where

$m=\left(\Sigma a_{n} / A_{o}\right)(1 / \sqrt{ } \Sigma t)$, is the slope of the straight line $\left(d^{-1 / 2}\right)$.

Method II: Rate equation for coupled diffusion and simultaneous first-order reaction

In this model, the rate equation is:

$$
\frac{\partial C}{\partial t}=D_{e}\left(\partial^{2} C / \partial X^{2}\right)+g(C)
$$

Here, the special case where $\mathrm{g}(\mathrm{C})$ is directly proportional to the concentration $\mathrm{C}$, i.e. a first-order reaction was considered. The initial and boundary conditions are,

$$
\begin{aligned}
& t=0, \alpha>x>0, C=C_{o} \\
& t=0, x<0, C=0 \\
& t>0, x=0, C=0
\end{aligned}
$$

From this, the fraction leached from a specimen having a surface area $\mathrm{S}\left(\mathrm{cm}^{2}\right)$ and volume $\mathrm{V}\left(\mathrm{cm}^{3}\right)$ is:

$$
\mathrm{f}=(\mathrm{S} / \mathrm{V}) \sqrt{\mathrm{D}_{\mathrm{e}} / \mathrm{k}}[(\mathrm{kt}+1 / 2) \operatorname{erf} \sqrt{\mathrm{kt}}+\sqrt{\mathrm{kt} / \pi} \exp (-\mathrm{kt})]
$$

Where $\mathrm{k}$ is the rate constant of the first-order reaction and

$$
\operatorname{erf}(u)=(2 / \sqrt{\pi}) \int_{o}^{u} \exp \left(-z^{2}\right) d z
$$

\section{Method III: Polynomial equation}

The orthogonal polynomial is one of the most useful empirical equations. Its general form is:

$$
y(x)=\sum_{i=1}^{n} A_{i} \phi_{i}(x)
$$

where:

$A_{i}$ - is the parameter to be determined, and

$\varphi_{\mathrm{i}}-$ is a function of $\mathrm{x}$. Here, $\varphi_{\mathrm{i}}(\mathrm{x})-$ is taken as $\mathrm{t}^{\mathrm{i} / 2}$, and the leaching fraction is given by

$$
f=\sum_{i=1}^{n} A_{i} t^{i / 2}
$$

To simplify the mathematical treatment, a fourth terms polynomial of the form

$$
f=A_{0}+A_{1} t^{1 / 2}+A_{2} t+A_{3} t^{3 / 2}
$$

was fitted to the leaching data. For this type of model, extrapolation to longer term leaching is not advisable since the arbitrary constants do not necessarily have any physical significance.

\section{Preparation of sample for leaching test}

More then 100 different formulations of concrete formulations were examined to optimize their mechanical and sorption properties. The concrete samples were prepared with a standard Portland cement PC-20-Z-45 MPa. The concrete composition was mixed with artificial radioactivity of ${ }^{60} \mathrm{Co}, \mathrm{A}_{\mathrm{o}}=55-67(\mathrm{kBq})$. Mixing time was about ten minutes. The mixtures were cast into $50 \mathrm{~mm}$ diameter cylindrical molds with a height of $50 \mathrm{~mm}$, which were then sealed and cured for 28 days prior to the leaching experiments. Leaching of ${ }^{60} \mathrm{Co}$ was studied using the method recommended by the IAEA [12] The duration of leachant renewal period was 30 days. After each leaching period the radioactivity in the leachant was measured using EG\&GORTEC spectrometry system and software. In this paper we discuss four representative formulations of concrete for filling trenches: $\mathrm{C}_{1}, \mathrm{C}_{2}, \mathrm{C}_{3}$ and $\mathrm{C}_{4}$. Composition and initial radioactivity $\mathrm{A}_{0}\left(\mathrm{~B}_{\mathrm{q}}\right)$ per sample prepared for leakage test, is shown in Table I.

\begin{tabular}{lcccc} 
& \multicolumn{5}{c}{ Formula } \\
Materials & $\mathrm{C}_{1}$ & $\mathrm{C}_{2}$ & $\mathrm{C}_{3}$ & $\mathrm{C}_{4}$ \\
\hline Cement (Portland), gr & 400 & 410 & 420 & 430 \\
\hline Sand, 0-2 mm & 846 & 584 & 700 & 670 \\
\hline Aggregate, 2-4mm & 522 & 520 & 512 & 310 \\
\hline Aggregate, 4-8mm & 432 & 686 & 598 & 890 \\
\hline Water, ml & 180 & 180 & 180 & 180 \\
\hline Additives, ml & 4 & 4 & 4 & 4 \\
\hline Initial activity $\mathrm{A}_{\mathrm{o}}(\mathrm{kBq})$ & \multicolumn{5}{c}{ Per sample } \\
${ }^{60} \mathrm{Co}$ & \multicolumn{5}{c}{ 60,0 } \\
\hline
\end{tabular}

Table 1. Concrete compositions (calculated as grams for $1000 \mathrm{~cm}^{3}$ of samples) 1. táblázat Beton összetételek (1000 $\mathrm{cm}^{3}$ térfogatú mintákra számítva)

\section{Results}

Experimental data show the fractions of ${ }^{60} \mathrm{Co}$ leached from concrete composite as a function of the square root of the leaching period. The linear relation between $f$ and $t$ is not observed throughout the test period. From the application of Method I to the leaching data we obtained:

$$
\begin{aligned}
& \mathrm{f}_{\mathrm{I}}\left(\mathrm{C}_{1}\right)=2,210^{-5} \mathrm{t}^{1 / 2}+7,610^{-9} \\
& \mathrm{f}_{\mathrm{I}}\left(\mathrm{C}_{2}\right)=3,910^{-5} \mathrm{t}^{1 / 2}+5,810^{-9} \\
& \mathrm{f}_{\mathrm{I}}\left(\mathrm{C}_{3}\right)=4,410^{-5} \mathrm{t}^{1 / 2}+6,310^{-9} \\
& \mathrm{f}_{\mathrm{I}}\left(\mathrm{C}_{4}\right)=5,510^{-5} \mathrm{t}^{1 / 2}+7,510^{-9}
\end{aligned}
$$

The diffusion coefficients predicted by Method I are:

$$
\begin{aligned}
& \mathrm{D}_{\mathrm{I}}\left(\mathrm{C}_{1}\right)=5,510^{-6}\left(\mathrm{~cm}^{2} / \mathrm{d}\right) \\
& \mathrm{D}_{\mathrm{I}}\left(\mathrm{C}_{2}\right)=5,910^{-6}\left(\mathrm{~cm}^{2} / \mathrm{d}\right) \\
& \mathrm{D}_{\mathrm{I}}\left(\mathrm{C}_{3}\right)=6,310^{-6}\left(\mathrm{~cm}^{2} / \mathrm{d}\right) \\
& \mathrm{D}_{\mathrm{I}}\left(\mathrm{C}_{4}\right)=7,810^{-6}\left(\mathrm{~cm}^{2} / \mathrm{d}\right)
\end{aligned}
$$

Method II was applied to the leakage data to obtain the unknown parameters $\mathrm{D}_{\mathrm{e}}$ and $\mathrm{k}$. From this we obtained: 


$$
\begin{aligned}
& \mathrm{D}_{\mathrm{II}}\left(\mathrm{C}_{1}\right)=3,5010^{-6}\left(\mathrm{~cm}^{2} / \mathrm{d}\right) \\
& \mathrm{D}_{\mathrm{II}}\left(\mathrm{C}_{2}\right)=4,9010^{-6}\left(\mathrm{~cm}^{2} / \mathrm{d}\right) \\
& \mathrm{D}_{\mathrm{II}}\left(\mathrm{C}_{3}\right)=5,7310^{-6}\left(\mathrm{~cm}^{2} / \mathrm{d}\right) \\
& \mathrm{D}_{\mathrm{II}}\left(\mathrm{C}_{4}\right)=6,7010^{-6}\left(\mathrm{~cm}^{2} / \mathrm{d}\right)
\end{aligned}
$$

Using the least squares procedure, Method III yielded:

$$
\begin{aligned}
& \mathrm{f}_{\text {III }}\left(\mathrm{C}_{1}\right)=7,610^{-8}+5,710^{-5} \mathrm{t}^{1 / 2}+5,310^{-8} \mathrm{t}+9,510^{-12} \mathrm{t}^{3 / 2} \\
& \mathrm{f}_{\text {III }}\left(\mathrm{C}_{2}\right)=5,810^{-8}+6,810^{-5} \mathrm{t}^{1 / 2}+6,610^{-8} \mathrm{t}+9,410^{-12} \mathrm{t}^{3 / 2} \\
& \mathrm{f}_{\text {III }}\left(\mathrm{C}_{3}\right)=4,310^{-8}+7,410^{-5} \mathrm{t}^{1 / 2}+6,610^{-8} \mathrm{t}+9,710^{-12} \mathrm{t}^{3 / 2} \\
& \mathrm{f}_{\text {III }}\left(\mathrm{C}_{4}\right)=3,610^{-8}+7,210^{-5} \mathrm{t}^{1 / 2}+9,810^{-8} \mathrm{t}+9,710^{-12} \mathrm{t}^{3 / 2}
\end{aligned}
$$

Figure 1. and Figure 2. present plots of $\mathrm{f}$ against $\mathrm{t}$ for leakage of ${ }^{60} \mathrm{Co}$ from the four concrete samples, for Methods I and Method III.

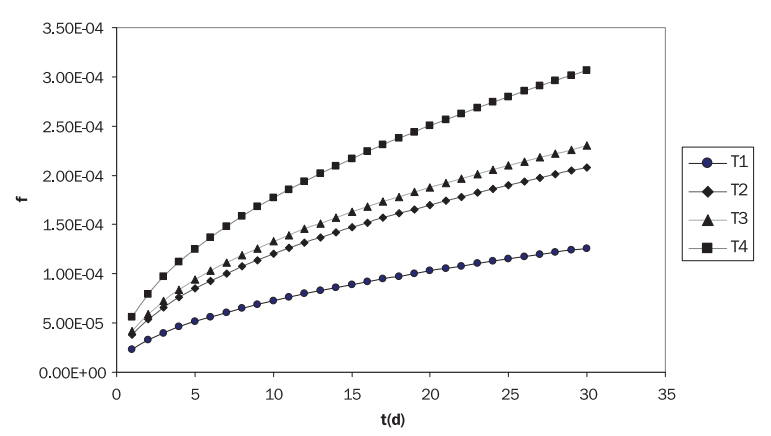

Fig. 1. Plot of fagainst $t$ (d) for leakage rate of ${ }^{60}$ Co from concrete (Method I) 1. ábra Azfés $t$ (d) összefüggése a ${ }^{60}$ Co betonból való szivárgásának sebességénél (I. módszer)

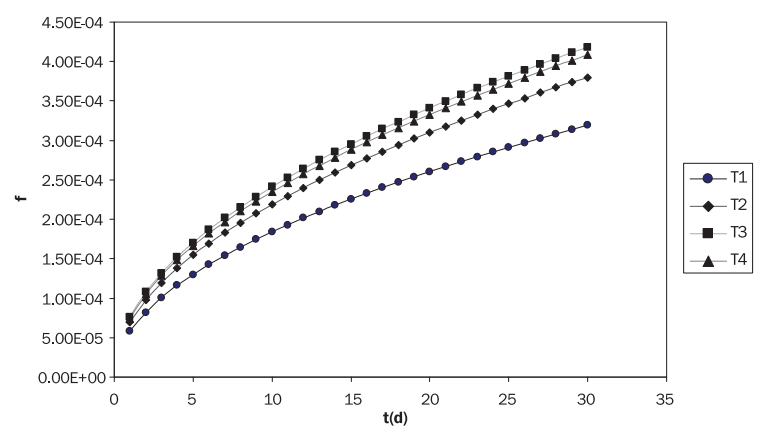

Fig. 2. Plot of fagainst $t$ (d) for leakage rate of ${ }^{60}$ Co from concrete (Method III) 2. ábra Azfés $t(d)$ összefüggése a ${ }^{60}$ Co betonból való szivárgásának sebességénél (III. módszer)

\section{Discussion and conclusion}

Results are presented in Fig 1. and 2. which shows the fraction of ${ }^{60} \mathrm{Co}$ leached from cement composites as a function of the square root of leaching period. In the data for cement composite as a matrix , linearity between $\mathrm{f}$ and $\mathrm{t}(\mathrm{d})$ is not observed throughout the time tested; however, there are two different linearity before and after a leaching time of about 10 days. The slope of the linear relation for the early stage is larger than for the latter one. This change in the leaching rate may be associated with the fact that, as the leaching time elapsed, the diffusion rate would gradually slow down as the diffusion path becomes longer. Method I cannot describe the whole leaching process; but it is very convenient to simulate leaching over a long period because of its simplicity. Despite the very complex numerical treatment required, the fit obtained using Method II is no better than that obtained using Method I. Method III provides the best approximation over the whole leaching period. In many cases, however, the leaching mechanisms are unknown and therefore, it is convenient to use polynomial approximation. Finally, the results presented in this paper will define the design of our future engineered trenches disposal system for radioactive waste.

\section{Acknowledgements}

Work supported by the Ministry of Science and Technology of the Republic of Serbia.

\section{References}

[1] I. Plecas - Lj. Mihajlovic - A. Kostadinovic: Radioactive waste management and nuclear fuel cycle, 6 (2), 161 (1985)

[2] I. Plecas - R. Pavlovic - S. Pavlovic: Bull. Mater. Sci, 26 (7), 699 (2003)

[3] I. Plecas: Annals of Nuclear Energy, Elsevier, 30/18, 1899 (2003)

[4] I. Plecas: Acta Chem. Slovenica, 50/3, 593 (2003)

[5] I. Plecas: Journal of Radioanalytical and Nuclear Chemistry, 258, 435 (2003)

[6] H. Matsuzuru - N. Moriyama -Y. Wadachi - A. Ito: Health Phys., 32, 529 (1977)

[7] N.J. Ojovan - I.V. Starceva - I.A. Sobolev - M.I. Ojovan - G.N. Chuikova: Proc.WM'04 Conference, 2004, Tucson, Arizona, 4090. pdf. 2004.

[8] I. Plecas - J. Drljaca - A. Peric - A. Kostadinovic - S. Glodic: Radioactive Waste Management and the Nuclear Fuel Cycle, 14.195 (1990)

[9] U.N. Yepimakov - M.S. Oleinik: Ecological Chemistry, 9, 116 (2000)

[10] N. Morijama - D. Dojiri - H. Matsuzuru: Health Phys.,33, 549 (1977)

[11] I. Plecas - A. Peric - A. Kostadinovic - J. Drljaca: J. Radioanal. Nucl. Chem., Lett., 154, 121 (1991)

[12] E.D. Hespe: AtomicEnergy Rev., 9, 195 (1971)

[13] J.L. Seveque, M.D. Cayeux , M. Elert and H. Nouguier: Cement and Concrete Research, 22, 477 (1992)

[14] C.E. Majorana and V.A. Salomoni: Journal of Hazardous Materials,113,45 (2004) 